DOI https://doi.org/10.30525/978-9934-26-110-7-66

\title{
ТРАНСФОРМАЦІЇ У ПЕРЕКЛАДІ БЕЗЕКВІВАЛЕНТНОЇ ТЕРМІНОЛОГІЇ У ТВОРАХ НАУКОВОЇ ФАНТАСТИКИ
}

\author{
Чумак Г. В. \\ кандидат філологічних наук, \\ дочент кафедри перекладу \\ Тернопільський національний педагогічний університет \\ імені Володимира Гнатюка \\ Деркач Г. С. \\ кандидат філологічних наук, \\ викладач кафедри іноземних мов \\ Тернопільський національний педагогічний університет \\ імені Володимира Гнатюка \\ м. Тернопіль, Украӥна
}

Найчастіше термінологія з'являється в науково-фантастичних текстах, які $\epsilon$ надзвичайно цікавим явищем для лінгвістичного та перекладацького аналізу, оскільки поєднують науковий та художній стилі. Такі тексти насичені термінологічними одиницями та безеквівалентною лексикою, тому адекватний переклад $є$ досить складним завданням.

Для дослідження були обрані твори збірника науково-фантастичних оповідань Айзека Азімова «Я, Робот». Збірка «Я, Робот» унікальна тим, що $є$ першою спробою Азімова з різних точок зору відобразити один із проблемних аспектів - зіткнення високих технологій i моральності. Аналізуючи оповідання Айзека Азімова, варто зазначити, що письменник використав велику кількість науково-технічних термінів, для того щоб перенести нас у світ фантастики та далекого майбутнього.

Одну 3 найскладніших для перекладу груп лексичних елементів становить безеквівалентна лексика, оскільки такі терміни були вжиті вперше або ж були вжиті лише в попередніх творах автора. Існують різні види трансформацій у перекладі безеквівалентної лексики.

Основним видом лексичної трансформації у перекладі - це транскодування. Багато термінів із циклу оповідань Айзека Азімова «Я, робот» передано українською мовою шляхом транскодування, тобто таким способом перекладу, коли звукова та/або графічна форма слова вихідної мови передається засобами мови перекладу. За В.I. Карабаном 
перекладені цим способом терміни можна розділити на 4 групи відповідно до видів транскодування [4, с. 282]. Перша група представлена термінами, перекладеними за допомогою транскрибування, наприклад: diameter - diaмeтp, metronome - метроном. До другої групи відносяться терміни перекладені способом транслітерації, наприклад: signal - сигнал, radio - padio, robot - poбom, patent - патент. Третя група представлена термінами, переданими змішаним транскодуванням (переважне застосування транскрибування із елементами транслітерування), наприклад: electro-magnet - електромагніт, relay - pеле. Четверта група термінів передана за допомогою адаптивного транскодування, коли форма слова в вихідній мові дещо адаптується до фонетичної та/або граматичної структури мови перекладу, наприклад: cybernetics - кібернетика, hypertrophy - гіпертрофований, selenium - селеній, stratosphere cmpamocфepa

Одним із прийомів відтворення технічної термінології $є$ калькування (дослівний або буквальний переклад), коли відповідником простого чи (частіше) складного слова (терміна) вихідної мови в цільовій мові вибирається, як правило, перший за порядком відповідник у словнику [4, c. 286]. Даний прийом використовується у перекладі складних за структурою елементів, наприклад: blunt-nosed spaceship - тупоносий космічний корабель, machinery accurate stereoscopy - стереоскопічна точність машини, photo-cell banks - батареї фотоелементів.

При перекладі термінів також застосовується і прийом генералізації. Генералізація вихідного значення має місце в тих випадках, коли міра інформаційної упорядкованості вихідної одиниці вища за міру упорядкованості, що відповідає їй за змістом у мові перекладу [3, с. 46], наприклад, Enceclopedia Tellurica - енщиклопедія, calculating machines обчислювальна техніка.

Модуляція або смисловий розвиток - це заміна слова або словосполучення іноземної мови, значення яких можна вивести логічним шляхом 3 вихідного значення. Найтиповішим прикладом смислового розвитку генералізації є причино-наслідкове відношення, наприклад: calculating machines (словниковий відповідник - обчислювальні машини) - обчислювальна техніка; або коли продукти діяльності замінюються суб'єктами діяльності, наприклад: They were in the radio room now - with its already antiquated equipment [8, с. 38]. - Вони увійшли до радіорубки. Ї̈ обладнання... трохи застаріло [1, с. 28].

У перекладі циклу Айзека Азімова «Я, робот» використовуються і лексико-граматичні трансформації, до яких відносяться антонімічний 
переклад, експлікація або описовий переклад, додавання, вилучення i контекстуальна заміна.

Антонімічний переклад представлений трьома видами:

1) негативізація (слово або словосполучення без формально вираженої суфіксом або частково заперечної семи замінюється в перекладі словом 3 префіксом не-або словосполученням з часткою не), наприклад: a rough circle - нерівне коло;

2) позитивізація (слово або словосполучення з формально вираженою заперечною семою замінюється в перекладі на слово або словосполучення, які не містять формально вираженого негативного компонента), наприклад: inoperable - вимкнений;

3) анулювання двох наявних у реченні негативних семантичних компонентів, наприклад: He was not no machine. - Робі всього-на-всього залізяка.

Передача деяких технічних термінів можлива завдяки описовому перекладу, коли слово, словосполучення, термін чи фразеологізм замінюється в мові перекладу словосполученням (або більшим за кількістю компонентів словосполученням), яке адекватно передає зміст цього слова або словосполучення (терміна). До описового перекладу висувають такі вимоги: 1) переклад повинен точно відбивати основний зміст позначеного терміном поняття; 2) опис не повинен бути надто докладним; 3) синтаксична структура не словосполучення не повинна бути надто докладною, наприклад: mobile speaking robot - pухомий робот, який здатний говорити, L-tиbe - вакуумні трубки дециметрового передавача.

Вилучення або компресія - це вид трансформації, до якого найчастіше всього звертаються, коли певна лексична одиниця є семантично надлишковою, тобто виражає значення, яке може бути зрозумілим 3 контексту [3, с. 48]. Часто компресія може супроводжуватися вилученням слова, наприклад: unorganized body signal - немодульований сигнал, light filters - світофільтри, robot's molasses-slow brain - роботтугодум, chemically treated cork layers - хімічно оброблений корок), machine-oil - мастило, air-pressure - тиск, photoelectric cell фотоелемент, heat resistant plastic- термостійкий пластик.

Інколи словниковий варіант не відповідає нормам перекладу або ж просто не звучить у реченні, тому, аби не порушувати стилістичну цілісність тексту, використовують трансформацію контекстуальної заміни. Даний вид трансформації поєднує в собі елементи і використовує прийоми як лексико-семантичних, так і лексико-граматичних перетворень [3, с. 49]. Прикладами контекстуальної заміни є такі слова та 
словосполучення, як maximum acceleration - шалена швидкість, coagulate-випікати, circuit-дpim.

Як було зазначено раніше, у творах наукової фантастики використовують лексику вузького стилістичного призначення, до складу якої входять неологізми. Авторські термінологічні неологізми можна виділити також і у творах циклу «Я, робот», що виконують як номінативну, так і стилістичну функцію. Нові лексичні одиниці є семантичними новоутвореннями, тобто вже відомі слова набувають нового значення самостійно або у словосполученні з іншим словом.

Прикладом можуть бути такі лексеми, як positronic brain - noзитронний мозок, head-set radio sender - шолом 3 вмонтованим радіоприймачем, photoelectric eуes - фотоелектричні очі, chest plate щчиток на грудях, non-speaking models - «німі» моделі, chromesteel arms сталеві руки, Stillhead Dielectrode Plate - діелектрична установка Стіллхеда, Mitchell Translation Equation - перехідне рівняння Мітчелла, hyperatomic drive - гіператомний двигун. Також серед неологізмів у цьому тексті трапляються лексичні інновації, утворені шляхом словоскладання та афіксації, наприклад, insosuit - скафандр, visiplate - екран, visiphone - візіфон, ingrooved - запрограмований.

Сутність усіх розглянутих нами трансформацій полягає в тому, що вони сприяють адаптації тексту оригіналу до норм та традицій цільової мови і досягненню максимальної зрозумілості перекладу. Їх використання відіграє особливо важливу роль у відтворенні безеквівалентної лексики у перекладі наукової фантастики.

\section{Література:}

1. Азімов А. Я, робот: зб. оповідань. Київ, 2010. 163 с.

2. Андрієнко Л.О. Науково-технічний переклад. Черкаси: ЧДТУ, 2002. $92 \mathrm{c}$.

3. Білозерська Л.П. Термінологія та переклад: навч. посіб. для студ. філол. напряму підготовки. Вінниця: Нова Книга, 2010. 232 с.

4. Карабан В.І. Переклад англійської наукової і технічної літератури: граматичні труднощі, лексичні, термінологічні та жанрово-стилістичні проблеми: посіб. з англ. мови і пер. для студ. вузів. Вінниця: Нова Книга, 2004. $576 \mathrm{c}$.

5. Катиш Т.В. Особливості функціонування термінологічної лексики в мові української фантастики: автореф. дис. ... канд. філол. наук. Д., 2005. $19 \mathrm{c.}$

6. Павлова О. Проблема перекладу термінів у художній літературі. Украӥнська наукова термінологія: зб. матеріалів наук.-практ. конф. 
"Украӥнська наук. термінологія. Проблеми перекладу". К.: Наук. думка, 2009. № 2. C. 191-197.

7. Хмара А. С. Особливості перекладу термінів та неологізмів у творах наукової фантастики. Науковий вісник Волинського наиіонального університету імені Лесі Украӥнки. Київ: НТУУ, 2010. Вип. 9. С. 241-244.

8. Asimov I. I, Robot. Reprinted in the UK by Voyager, 2001. $256 \mathrm{p}$.

DOI https://doi.org/10.30525/978-9934-26-110-7-67

\title{
LITERARY TEXT ORIGINAL MESSAGE IN RAY BRADBURY'S SHORT STORIES TRANSLATIONS
}

\author{
Yashkina V. V. \\ Candidate of Philological Sciences, \\ Associate Professor at the Department of English Philology \\ Oles Honchar Dnipro National University
}

Haidar V. P.

Teacher at the Department of English Language

for Non-Philological Specialities

Oles Honchar Dnipro National University

Dnipro, Ukraine

The given research is aimed to consider the key aspects of the theory of translation as well as the peculiarities of their practical application on the basis of Ray Bradbury's short stories [2] in German and Ukrainian translations.

Translation is a complex phenomenon influenced by a variety of factors, including linguistic features and cultural aspects. Its main task is to implement interlingual and intercultural communication providing the exact transmission of the content, form and style of the outgoing message.

The process of translation normally implies certain correspondences between the language units of the source and target language. Such correspondences describe the notion of translation equivalence, which is understood as the reproduction of informative, semantic and stylistic filling of the message by substituting units of the original text with their equivalents in the language of translation. However, equivalent translation is not enough for accurate reproduction of the information, since it is not always adequate. Adequacy of translation means the maximum correspondence of reality, depicted in the original, with the preservation of the content, form and 